\title{
Ergonomic Design of Public Bus in The Philippines with Provision for Senior Citizens and Persons with Disability
}

\author{
Ma. Janice J. Gumasing ${ }^{1, *}$ and Charm Hanalae C. Dela Cruz ${ }^{1}$ \\ ${ }^{1}$ School of Industrial Engineering and Service Engineering Management, Mapúa University 658 Muralla St., Intramuros, Manila 1002 , \\ Philippines
}

\begin{abstract}
Comfortability in buses for commuters particularly those with special needs such as senior citizen and person with disability is a concern, which requires attention. Public buses are highly used mode of transportation in the Philippines, both provincial and city. In this work, the researchers aim to determine the design factors that affect the comfortability of commuters and eventually come up with an ergonomic design of public bus to be used in the Philippines with provision for senior citizen and persons with disability. The study covers and mainly focused on designing bus doors and its interior for the accessibility of the senior citizens and persons with mobility aid such as wheelchairs, crutches and canes ergonomically. The researchers have conducted review of related literature, direct observation, surveys, interviews and actual measurements of bus dimensions in order to describe factually and accurately the current design of buses in the Philippines. The researchers have improved the current design of provincial public buses having trips from Cavite to Manila (vice versa) with consideration of the issues and needs of the commuters in riding a bus.
\end{abstract}

\section{Introduction}

Transportation is the movement of people or goods from one place to another that supports human's daily activities. According to Dr. Romulo A. Virola, Secretary General of National Statistical Coordination Board (NSCB), transportation plays a vital role in the development of a country's economy. The most accessible and commonly used mode of transportation in the Philippines is by land and is known to contribute more than three times the combined Gross Value Added of water and air transportation with a 26.63 percent share to the total GVA in transport in year 2013 [1]. GDP defined by Webster as a measure in economics of the value of goods and services produced in a country while GVA is a measure in economics of the value of goods and services of an area, industry or sector.

It is one of the basic needs in life and is part of our normal routine. And with the vast increase in population, the NSCB predicts that people aging $60+$ represented $5.97 \%$ is expected to grow to $13.8 \%$ of the population by 2040 while persons with disability is said to be 1.57 percent of 141.7 million Filipinos according to National Statistics Office (NSO) [2]. This will have a massive impact on public transport. Thus, there are things that unfairly prevent many incapable commuters from using public transports to fully participate in society.

On the study regarding mobility restriction of the elderly conducted by Matthias Fiedler [3], he stated, as the age increases, the likeliness of impairments that affects mobility also increases. In addition, the work done by [4] stated that recommended that in order to fulfill the needs of people with disabilities, the transport infrastructure and mobility factor for the disable has to be assessed and improved. A study done by [5] has stated that bus design and service provision has relative impact on the usage of bus by older people. The study by [6] has described that travel experiences of older and people with disability has to be taken into account to the progress of quality mode of transport for all. A study by [7] has discussed that for the people with disabilities, the current conventional urban public transport system could not deliver an efficient service and limitation still exist. A study by [8] concluded that restricted mobility caused by the existing transport system and design is still a major concern for older people using the bus service.

Therefore, this evidently shows the need to improve the quality of transportation for persons with disabilities and for senior citizens $[9,10]$. Prior researches focused on the evaluation of the measurements of curb, bus entrance/exits steps, safety handrails and the required distance between them, for the incapacitated passengers to board/alight $[9,10]$. The design devoted for passengers with mobility impairments and the older people seems to be an issue for other commuters. The problem on integration of the designs fit to use to various commuters continue to exist. Also, currently there is no existing studies/researches applicable here in the Philippines.

That being so, the researchers aimed to ergonomically design a bus including the entrance/exits doors and its

* Corresponding author: mjjgumasing@mapua.edu.ph 
interior that is fit to use for Filipino commuters; the bus is equipped with area guards to ensure the security of the passengers during the loading and unloading process as well as the whole duration of the trip. This study also aimed to minimize the effort and assistance from all the concerned commuters and operator. The design is dedicated to all types of passengers but most especially for those who have mobility aids and are incapable of riding a bus with ease of use, safety and accessibility.

The study covers and mainly focused on designing bus doors and its interior for the accessibility of the senior citizens and persons with mobility aid such as wheelchairs, crutches and canes ergonomically. The researchers have improved the current design of provincial public buses having trips from Cavite to Manila (vice versa) with consideration of the issues and needs of the commuters in riding a bus. The researchers used the population within the area as respondents in this study. Having said that, it does not cover the engine specifics, aesthetics and other designing aspects of the bus. Engine specifics include the mechanical features to be used and as per aesthetics, it is a guiding principle in matters of artistic beauty and taste.

\section{Methodology}

In pursuing and coming up with a result, the study followed a framework that is shown in Figure 1 which provided this paper a structure and a guideline to come up and to have a clear idea on what and how the output design was constructed.

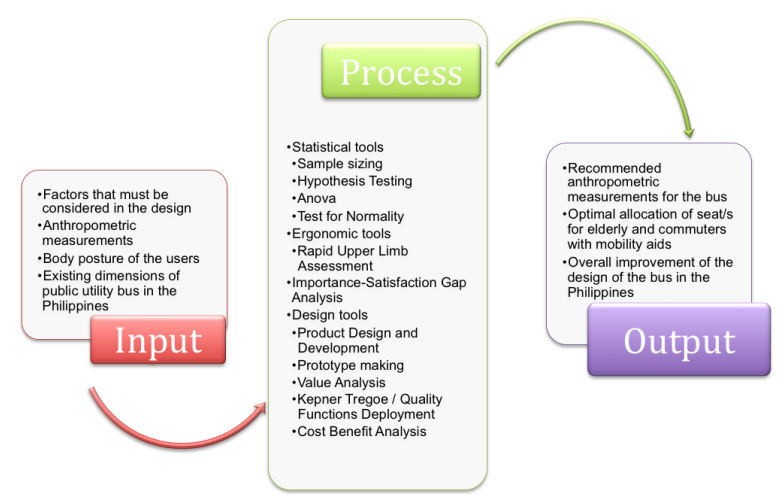

Fig. 1. Research Framework

\subsection{Data Collection}

The researchers have conducted review of related literature, direct observation, surveys, interviews and actual measurements of bus dimensions in order to describe factually and accurately the current design of buses in the Philippines. The researchers were able to identify factors that will be considered in the design of ergonomic bus in the Philippines such as anthropometric measurements of users, body posture of users, and actual dimensions of public buses in the Philippines. Data were collected by manually measuring the dimensions of the bus and afterwards incorporated for the proposed design. Along with the measurement of safety devices and anthropometrics, normal passengers and elderly were treated separately due to independent demand and measurements. - Body posture of the users assessed are boarding and alighting postures; this was done to eliminate tension, stress and musculoskeletal disorder in riding a public bus.

The researcher also conducted an assessment and the current state of the bus safety devices, measurements and its effectiveness and efficiency along with the anthropometric measurements that an average Filipino bus passenger would require from such specifics like height, width, and the like. The gathered results and measurements had shown the gap from the current measurements to the ideal and user-demanded specifics and had become the basis for formulation and design of the proposed improvement prototype intended for utilization for the senior citizens, persons with disabilities, and lastly average Filipino commuter. But actual measurements were gathered and measured on the buses routing Manila-Cavite and vice versa.

\subsection{Data Analysis}

Factors obtained from data gathering procedure were recorded, described, interpreted and analyzed. Statistical analyses and treatments such as sample sizing, hypothesis testing, analysis of variance and test for normality were also conducted in order to systematically and statistically investigate and explain the nature of relationship between factors considered in the study. The researchers also evaluated the current posture of bus users in the Philippines including the senior citizens and persons with disability through ergonomic tool such as Rapid Upper Limb Assessment (RULA). This tool estimates the risk of upper-limb disorders based on the posture of the subject. In addition to this, the researchers also performed Importance-Satisfaction Gap Analysis to determine the importance of the design attributes of the bus to the users. And finally, in order to come up with an ergonomic design of bus with provision for senior citizen and persons with disability, the researchers made use of design tools such as product design and development, prototype making, value analysis, Kepner-Tregoe technique, Quality Functions Deployment technique and cost-benefit analysis.

As per the output phase, once all data has been gathered, computed and processed, the researcher has come up into a conclusion of designing an effective and efficient bus layout specifically crafted with respect to the recommended anthropometric measurements that will cater the needs of an average elder and/or persons with disabilities and for them to take advantage of the transportation service that is widely provided by the bus lines within the coverage of the study. This research has delivered an overall improvement design of buses in the Philippines including the optimal number of seats for elderly and commuters with mobility aids that does not compromise the earnings and service rate of bus companies. 


\section{Results and Discussion}

Subsequent to computation of sample size, bus lines are measured and tested using hypothesis testing and analysis of variance (ANOVA) for further assessment. Door clearance including step height, step width, step depth, vertical and horizontal clearance for the mobility aids that will enter the bus and the seat depth, seat width, seat height, leg clearance, backrest height, overhead handrails height, stanchion height, stanchion length, stanchion width, compartment level height and aisle width that depends on the measurements of people with disabilities (PWD) and elderly with consideration on their physical limitations and anthropometrics.

The researchers have managed to measure each specification on each bus line at Philippines including San Agustin, Erjohn and Almark, Don Aldrin, Starliner, Dionets, Lorna Express and St. Anthony of Padua. Each liner's newest bus units are chosen knowing that it was improved as compared to their old units.

As for validation of the bus design measurements, hypothesis testing and ANOVA was deployed using Statplus as shown in Table 1, where $\mu_{0}$ are the bus lines.

Table 1. Hypothesis Testing

\begin{tabular}{|c|l|}
\hline \multicolumn{2}{|c|}{ Hypothesis Testing } \\
\hline a & Null Hypothesis $\mathrm{H}_{0}: \mu_{1}=\mu_{2}=\mu_{3}=\mu_{4}=\mu_{5}=\mu_{6}=\mu_{7}$ \\
\hline b & $\begin{array}{l}\text { Alternative Hypothesis } \mathrm{H}_{\mathrm{a}}: \mu_{1} \neq \mu_{2} \neq \mu_{3} \neq \mu_{4} \neq \mu_{5} \neq \mu_{6} \\
\neq \mu_{7}\end{array}$ \\
\hline c & Confidence Level :95\% \\
\hline d & One - Way ANOVA \\
\hline
\end{tabular}

Based on the result of ANOVA, F value .08 is less than F critical, which is 2.19 , the claim is said to be true, do not reject null hypothesis. Therefore, bus liners' design has no significant difference. This study could assess only one bus line as comparison for the proposed design with appropriate measurements and improvements. Table 2 shows the ANOVA results.

Table 2. Anova Results

\begin{tabular}{|c|c|c|c|c|}
\hline \multicolumn{5}{|c|}{ Analysis of Variance (One-Way) } \\
\hline \multicolumn{5}{|c|}{\begin{tabular}{l|l|l} 
Summary & & \\
\end{tabular}} \\
\hline Groups & $\begin{array}{l}\text { Sample } \\
\text { size }\end{array}$ & Sum & Mean & Var. \\
\hline San Agustin & 15 & 457 & 30.47 & 545 \\
\hline Erjohn & 15 & 457 & 30.47 & 545 \\
\hline Don Aldrin & 15 & 434.5 & 28.97 & 490 \\
\hline Starliner & 15 & 383.5 & 25.57 & 547 \\
\hline Dionets & 15 & 452 & 30.13 & 531 \\
\hline $\begin{array}{l}\text { Lorna } \\
\text { Express }\end{array}$ & 15 & 441.1 & 29.41 & 500 \\
\hline St. Anthony & 15 & 436. & 29.07 & 554 \\
\hline \multicolumn{5}{|l|}{ ANOVA } \\
\hline $\begin{array}{l}\text { Source of } \\
\text { Variation }\end{array}$ & $S S$ & $d f$ & $M S$ & $F$ \\
\hline $\begin{array}{l}\text { Between } \\
\text { Groups }\end{array}$ & 260.71 & 6 & 43.45 & 0.08 \\
\hline $\begin{array}{l}\text { Within } \\
\text { Groups }\end{array}$ & $\begin{array}{l}51,999 . \\
73\end{array}$ & 98 & 530.61 & \\
\hline
\end{tabular}

\begin{tabular}{|l|l|l|l|l|}
\hline Total & 52,260 & 104 & & \\
\hline
\end{tabular}

On account of gathering anthropometric measurements, the researchers verified the data set of 100 senior citizen respondents if was well modeled by a normal distribution. Each measurement (stature height, tibial height etc.) were tested and concluded based on the result individually using NumXL which computed the following results as shown in Table 2 .

Table 2. Anthropometric Measurement

\begin{tabular}{|l|l|l|}
\hline $\begin{array}{l}\text { Anthropometric } \\
\text { Measurement }\end{array}$ & $\begin{array}{l}\text { P- } \\
\text { Value }\end{array}$ & Pass? \\
\hline Stature & $7.3 \%$ & TRUE \\
\hline Tibial Height & $5.7 \%$ & TRUE \\
\hline Popliteal Height & $24.7 \%$ & TRUE \\
\hline Buttock to Knee & $5.7 \%$ & TRUE \\
\hline Buttock to Popliteal & $5.7 \%$ & TRUE \\
\hline Forward Reach & $7.1 \%$ & TRUE \\
\hline Sitting Height & $5.7 \%$ & TRUE \\
\hline Elbow to Wrist & $5.7 \%$ & TRUE \\
\hline $\begin{array}{l}\text { Sitting elbow } \\
\text { height }\end{array}$ & $5.7 \%$ & TRUE \\
\hline Hip Breadth & $5.6 \%$ & TRUE \\
\hline
\end{tabular}

Null Hypothesis was accepted because the P-value of each anthropometric data satisfied the condition that it should exceed alpha level of $5 \%$, and as computed by NumXL, the result above pass the Normality test. Therefore, the data collected of senior citizen anthropometric measurements are normally distributed and was verified to be reliable for use.

Behaviors of users at boarding and alighting were observed at bus stops. For the assessment of the body postures of commuters on different cases, the researchers took photos of persons with disabilities with mobility aids and elderly with normal condition and elderly using canes. The critical postures examined were the act of boarding and alighting because these are the positions that occur stress on the body of the commuters in accessing a bus and were also used for the Rapid Upper Limb assessment. The results of the RULA on different types of commuters has an average of 3-5 which dictates that the current bus design needs further investigation for improvement and implementation of the improved design as soon as possible to avoid risk on the users especially on PWD with mobility aids that requires more detailed and hazard free design considering their physical limitation and capabilities because it causes awkward position to its users that may lead to musculoskeletal disorder or even accidents.

Importance - Satisfaction Gap Analysis. The IS rating is a unique tool that allows the researchers to better understand both of the highly important decision making criteria of each of the service the bus company is providing. This method is based on the concept that companies will maximize commuter's satisfaction by improving the bus specifications where the level of satisfaction is relatively low and the perceived importance of the service is relatively high. 
Common problem among senior citizens is the height issue that is inevitable because they are having difficulty in moving or by just boarding themselves in highelevated flat-forms or stairs due to their physical capabilities, seniors also want their luggage near them or within sight. For the crutch users, aside from the height issues obviously because of their disability, leg clearance, space for maneuvering, and difficulty in reaching door safety handrails were the top concerns. Wheelchair users on the other hand has more demand as compared to other passengers since their mobility aid requires much space for securement and the mechanism of the doors so they board and alight safely. Last but not the least are the crutch users, they have the same assessment of the current bus as the others with addition on the importance of overhead bars and handrail heights, according to some PWD interviewed, since there is no strict policy of the reserved seats dedicated for them, they experience standing the whole trip so they needed something to hold on for stability and balance.

Now, House of Quality (HOQ) is where the design creation starts and it comes after all the assessment tools because customer issues and demands were already identified. The primary goal of Quality Function Deployment is to distinguish the problems that are vital to the planning process. By deploying HOQ, it helps the researcher to identify the technical attributes that has to be prioritized in the design aligned with the customer demands. The improved design was compared to competitor's design that allows the researcher to strategize on how to better satisfy the customer and identify where the design is weak that needs more attention. The researcher has translated customer demands to product specifications.

The proposed bus design measurements were established using anthropometrics, design and assessment tools. Table 3 shows the proposed bus door specifications. Table 4 shows the proposed bus seats specifications. Table 5 shows the proposed bus interior measurement

Table 3. Proposed Bus Door Specifications

\begin{tabular}{|c|c|c|}
\hline $\begin{array}{c}\text { Part } \\
\text { Specification }\end{array}$ & $\begin{array}{l}\text { Anthropometric } \\
\text { Measurement }\end{array}$ & $\begin{array}{c}\text { Measuremen } \\
t \text { (inches) }\end{array}$ \\
\hline $\begin{array}{c}\text { Door Vertical } \\
\text { Clearance }\end{array}$ & Standard & 83 \\
\hline $\begin{array}{c}\text { Door } \\
\text { Clearance } \\
\text { Width }\end{array}$ & $\begin{array}{c}\text { Maximum } \\
\text { Wheelchair Width } \\
+ \text { allowance }\end{array}$ & $\begin{array}{c}26.5+4 \\
=30.5\end{array}$ \\
\hline $\begin{array}{l}\text { Ramp Step } \\
\text { Height }\end{array}$ & $\begin{array}{l}\text { Curb Height and is } \\
\text { adjustable to } \\
\text { ground }\end{array}$ & 8 \\
\hline Ramp Length & Standard & 30 \\
\hline Ramp Height & Standard & 3 \\
\hline $\begin{array}{c}\text { Stanchion } \\
\text { Height }\end{array}$ & $\begin{array}{c}\text { Sitting shoulder } \\
\text { height }\left(50^{\text {th }} \text { male }\right. \\
\text { and female })+ \text { seat } \\
\text { height }\end{array}$ & $\begin{array}{c}21.07+14 \\
=35.07=35\end{array}$ \\
\hline $\begin{array}{l}\text { Stanchion } \\
\text { Length }\end{array}$ & Seat Width x 2 & $\begin{array}{l}24.6 \\
33.4\end{array}$ \\
\hline $\begin{array}{c}\text { Handrail } \\
\text { Height }\end{array}$ & $\begin{array}{l}\text { Standing Shoulder } \\
\text { Height } 5^{\text {th }} \text { female - }\end{array}$ & $\begin{array}{c}46.5-6= \\
40.5\end{array}$ \\
\hline
\end{tabular}

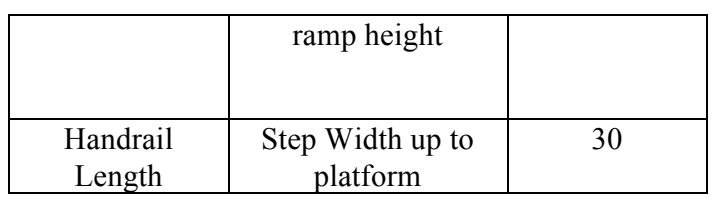

Table 4. Proposed Bus Seats Specifications

\begin{tabular}{|c|c|c|c|}
\hline $\begin{array}{l}\text { Bus } \\
\text { Specification }\end{array}$ & $\begin{array}{l}\text { Anthropometric } \\
\text { Measurement }\end{array}$ & Percentile & Inches \\
\hline Seat Height & Popliteal Height & $5^{\text {th }}$ female & $\begin{array}{l}\text { Normal :14 } \\
\text { Senior: } 13.41\end{array}$ \\
\hline Seat Depth & $\begin{array}{ll}\text { Buttock } & \text { to } \\
\text { Popliteal } & \end{array}$ & $5^{\text {th }}$ femla & $\begin{array}{l}\text { Normal:15.7 } \\
\text { Senior:12.49 }\end{array}$ \\
\hline Seat Width & Hip Breadth & $\begin{array}{l}95^{\text {th }} \\
\text { female }\end{array}$ & $\begin{array}{l}\text { Normal:16.70 } \\
\text { Senior:12.29 }\end{array}$ \\
\hline $\begin{array}{l}\text { Seat Cushion } \\
\text { Slope }\end{array}$ & Standard & & $8^{\circ}-15^{\circ}$ \\
\hline $\begin{array}{ll}\text { Arm } & \text { rest } \\
\text { Height } & \end{array}$ & $\begin{array}{ll}\text { Sitting } & \text { Elbow } \\
\text { Height } & \end{array}$ & $\begin{array}{l}5^{\text {th }} \\
\text { Female }\end{array}$ & $\begin{array}{l}\text { Normal:6.69 } \\
\text { Senior:6.63 }\end{array}$ \\
\hline $\begin{array}{ll}\text { Arm } & \text { rest } \\
\text { Lenght } & \end{array}$ & $\begin{array}{l}\text { Elbow to Wrist } \\
\text { or length of } \\
\text { lower arm }\end{array}$ & $\begin{array}{l}5^{\text {th }} \\
\text { Female }\end{array}$ & $\begin{array}{l}\text { Normal } 7.87 \\
\text { Senior:7.35 }\end{array}$ \\
\hline $\begin{array}{l}\text { Leg } \\
\text { clearance } \\
\text { Normal: } \\
\text { PWD: }\end{array}$ & $\begin{array}{l}\text { (Buttock to } \\
\text { Knee - Buttock } \\
\text { to Popliteal) } * 2 \\
\text { +allowance } \\
\text { Buttock to Knee } \\
+ \text { tibial height }- \\
\text { Buttock to } \\
\text { popliteal }\end{array}$ & $95^{\text {th }}$ male & $\begin{array}{l}(24.37- \\
20.47) * 2 \\
=8+2=10 \\
24.37+21.65- \\
20.47=25.55\end{array}$ \\
\hline $\begin{array}{l}\text { Backrest } \\
\text { Height }\end{array}$ & Sitting Height & $50^{\text {th }}$ male & $\begin{array}{l}\text { Normal: } \\
33.47 \\
\text { Senior: } 34.09\end{array}$ \\
\hline $\begin{array}{l}\text { Backrest } \\
\text { Width }\end{array}$ & Hip Breadth & $\begin{array}{l}95^{\text {th }} \\
\text { female }\end{array}$ & $\begin{array}{c}\text { Normal: } \\
16.70 \\
\text { Senior: } 12.29\end{array}$ \\
\hline $\begin{array}{l}\text { Backrest } \\
\text { Slope }\end{array}$ & Standard & & $8^{\circ}-17^{\circ}$ \\
\hline
\end{tabular}

Table 5. Proposed bus interior measurement

\begin{tabular}{|l|l|l|l|}
\hline $\begin{array}{l}\text { Bus } \\
\text { Specification }\end{array}$ & $\begin{array}{l}\text { Anthropometric } \\
\text { Measurement }\end{array}$ & Percentile & Inches \\
\hline Roof Height & $\begin{array}{l}\text { Standing } \\
\text { Height }\end{array}$ & $95^{\text {th }}$ male & 72 \\
\hline $\begin{array}{l}\text { Grab bar } \\
\text { Height }\end{array}$ & $\begin{array}{l}\text { Roof Height }- \\
\text { Luggage Space } \\
\text { Height }\end{array}$ & 60 \\
\hline $\begin{array}{l}\text { Luggage } \\
\text { Level Height }\end{array}$ & $\begin{array}{l}\text { Shoulder ht. + } \\
\text { length of upper } \\
\text { arm } \\
\text { allowance }\end{array}$ & $50^{\text {th }}$ female & 60 \\
\hline $\begin{array}{l}\text { Luggage } \\
\text { Space Height }\end{array}$ & - & - & 12 \\
\hline Aisle Width & & & 25.2 \\
\hline Hand Strips & Shoulder breath & $50^{\text {th }}$ & 17 \\
\hline
\end{tabular}




\begin{tabular}{|l|l|l|l|}
\hline $\begin{array}{l}\text { (wheelchair } \\
\text { area) }\end{array}$ & male & & \\
\hline
\end{tabular}

Figures 2 ,Figure 3 and Figure 4 shows the existing bus layout and design. Figure 5, Figure 6 and Figure 7 shows the proposed bus layout and design.

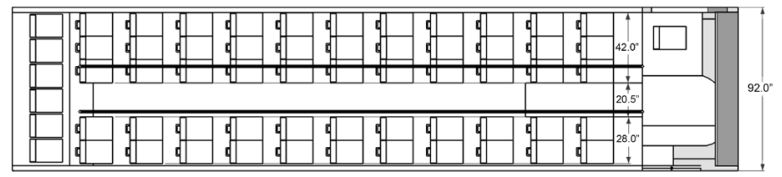

Figure 2. Bus layout top view (existing)

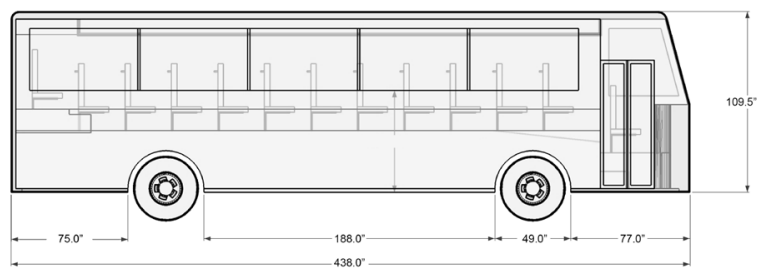

Figure 3. Bus layout side view (existing)

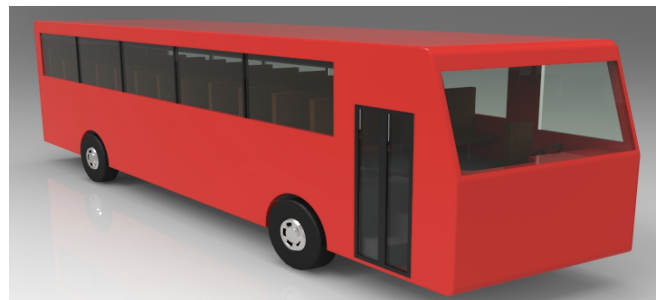

Figure 4. Bus 3D View (existing)

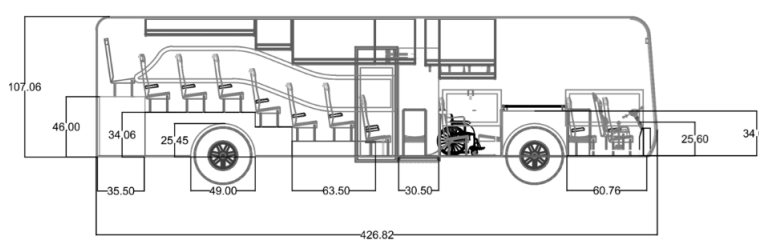

Figure 5.Bus layout top view (proposed)

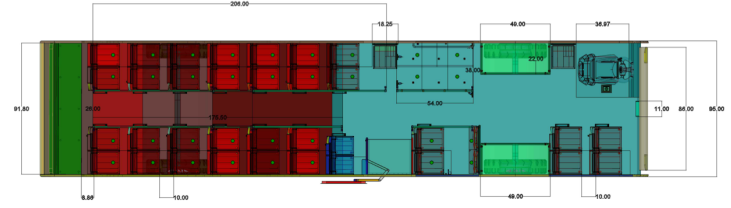

Figure 6.Bus layout side view (proposed)

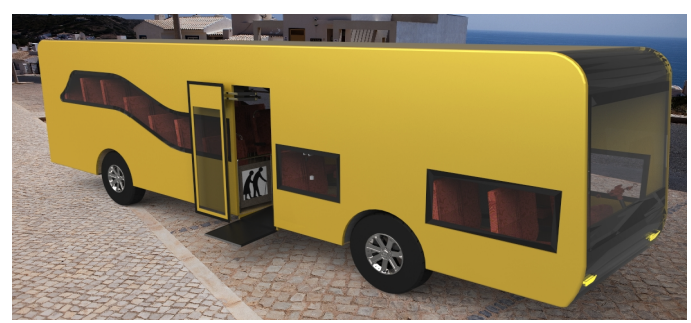

Figure7. Bus 3D View (proposed)

In addition, the cost analysis was also done. The customization price for the proposed designed is estimated at Php 6,134,008. Thus by comparing with the cost of the existing bus design, the following additional cost has been calculated.

$$
\begin{aligned}
\text { Total Cost } & =\text { Proposed Bus }- \text { Current Bus } \\
& =\text { Php 6,134,008 }- \text { Php 5,000,000 } \\
& =\text { Php 1,134,008 }
\end{aligned}
$$

The total cost of improving the current bus design is the cost of the proposed design with inclusion of the customization and the all the improved and added parts of the bus minus the cost of the current bus design. The value computed is the amount that the company is willing to pay or disburse in exchange of the accessibility of PWD and comfortability of its users Primarily, cost-benefit analysis has itemized all the improvements done in the creation of the design and discussed the benefits it will cause to the passengers as well as the things compromised to make way for the design prioritization to elderly and PWD. One of the highest cost contributor done to fulfill the objective of this study was decreasing the bus capacity, originally, a bus could accommodate up to 56-61 passengers on a single trip. Proposed bus design could now accommodate 43 passengers only including senior citizens and PWDs. If all passengers onboard are normal, 6 standing passengers could fill and utilize the wheelchair space. All in all, bus optimal capacity has reduced to 50, not much difference with the existing but with great improvement that provides ease, accessibility and comfort to the passengers.

\section{Conclusion}

The findings of this study have shown that major users of public buses who participated in this study were less satisfied and are having difficulty in the use of the current design of public buses in the Philippines. The dissatisfaction was evident on the scores generated by the rapid upper limb assessment computed from their body postures while boarding or alighting a bus that led to analysis and conclusion that they have physical limitations and issues. In addition, the current design measurements manifested to be not ergonomically designed or not fit for use for Filipino commuters. This claim is supported with statistical analysis, thus, the actual anthropometric measurements of Filipinos were used to ergonomically fit the design of the bus to the commuters. Furthermore, the equipment especially crafted for the passengers with mobility aids were added to suffice their necessity. The limitations and accessibility issues of the design has caused the passengers being deprived in utilizing the public transportation determined thru interviews and surveys of passengers aging 60 years of age above, passengers with disabilities and/or mobility aids. The customer demands or specifications were identified on the assessment conducted by the researchers using ImportanceSatisfaction Gap and as a result, the design attributes found to be important for the passengers but has less satisfaction given to them were considered to be the target specifications in product design and development. 
In other words, the concerns of the passengers and their requirement on the design were translated as final specifications of the proposed bus design as a guarantee of the fulfillment of the demand. However, the improvements of the current bus scenario cannot be possibly evaluated because this study does not require (and is not possible) to create a prototype.

The study has achieved its goal and made an overall improvement on the design of the current public bus in the Philippines with respect to Filipino anthropometric measurement favorable to the customer and the company.

\section{References}

1. Virola, R., Reyes, R., Polistico, F., and Oliveros, A. (2011) "Things Statisticians wanted to know about the Tourism Satellite Account but were afraid to ask," Retrieved March, vol. 3, p. 2014,

2. Virola, R. A., and Encarnacion, J. O. (2016) "The Washington Group on the Improvement of Disability Statistics Globally: Perspectives from the Philippines," in International Measurement of Disability, Springer, pp. 233-253.

3. Fiedler, M. (2007). Older people and public transport. Challenges and changes of an ageing society. Final report. Retried from: http://www. emta.

com/IMG/pdf/Final_Report_Older_People_protec. pdf.

4. Cavinato, J. L., \& Cuckovich, M. L. (1992). Transportation and tourism for the disabled: An assessment. Transportation Journal, 46-53.

5. Stern, S. (1993). A disaggregate discrete choice model of transportation demand by elderly and disabled people in rural Virginia. Transportation Research Part A: Policy and Practice, 27(4), 315327.

6. Ipingbemi, O. (2015). Mobility challenges and transport safety of people with disabilities (PWD) in Ibadan, Nigeria. AFRICAN JOURNAL FOR THE PSYCHOLOGICAL STUDIES OF SOCIAL ISSUES, 18(3), 15-27

7. Broome, K., McKenna, K., Fleming, J., \& Worrall, L. (2009). Bus use and older people: A literature review applying the Person-EnvironmentOccupation model in macro practice. Scandinavian journal of occupational therapy, 16(1), 3-12.

8. Hine, J., \& Mitchell, F. (2001). Better for everyone? Travel experiences and transport exclusion. Urban studies, 38(2), 319-332.

9. Zhou, H., Hou, K. M., Zuo, D., \& Li, J. (2012). Intelligent urban public transportation for accessibility dedicated to people with disabilities. Sensors, 12(8), 10678-10692.

10. Wretstrand, A., Svensson, H., Fristedt, S., \& Falkmer, T. (2009). Older people and local public transit: Mobility effects of accessibility improvements in Sweden. Journal of Transport and Land Use, 2(2). 